\title{
Utilization of Soil Solarization for Eliminating Viable Tilletia indica Teliospores from Arizona Wheat Fields
}

\author{
G. L. Peterson, United States Department of Agriculture-Agricultural Research Service (USDA-ARS), Foreign \\ Disease-Weed Science Research Unit, Fort Detrick, MD, 21702; K. L. Kosta, California Department of Food and \\ Agriculture, Sacramento 95814; D. L. Glenn, USDA-ARS, Foreign Disease-Weed Science Research Unit; and \\ J. G. Phillips, USDA-ARS, North Atlantic Area, Wyndmoor, PA 19038
}

\begin{abstract}
Peterson, G. L., Kosta, K. L., Glenn, D. L., and Phillips, J. G. 2008. Utilization of soil solarization for eliminating viable Tilletia indica teliospores from Arizona wheat fields. Plant Dis. 92:1604-1610.

Studies were conducted in Arizona to determine the efficacy of soil solarization for killing teliospores of the soilborne fungal wheat pathogen Tilletia indica. In a replicated study conducted in each of 3 years, $T$. indica teliospores and bunted wheat kernels were buried in a Karnal buntinfested wheat field at depths of 5,10 , and $20 \mathrm{~cm}$. Replicate samples were removed from under a clear plastic solarization cover at 7-day intervals and the number of viable teliospores determined. A rapid decline in teliospore viability occurred at all treatment depths over 38 days, with efficacy comparable with methyl bromide protocols using clear plastic sheeting. Initial viability rates of 43,71 , and $82 \%$ germination were reduced to $0.1,7.7$, and $0.2 \%$ after 38 days (across all depths) in 2003, 2005, and 2006, respectively. Mean daily maximum soil temperatures at 5 and $20 \mathrm{~cm}$ under clear plastic in 2003, 2005, and 2006 were 67,53 and $60^{\circ} \mathrm{C}$ and 43,38 , and $43^{\circ} \mathrm{C}$, respectively. Under current United States Department of Agriculture disease management strategies, the method may be useful for the rapid deregulation of Karnal bunt-affected fields.
\end{abstract}

Karnal bunt of wheat, caused by the fungus Tilletia indica Mitra, was first detected in the United States in limited regions in the state of Arizona and in Riverside County, CA in 1996 (42). One year later it was discovered in isolated areas of central and northern Texas (29). This soilborne, nonsystemic pathogen infects wheat at the time of flowering via secondary sporidia originating from basidiospores produced by germinating teliospores on the soil surface. The geographic distribution of the disease has been limited to arid and semi-arid environments, historically occurring on fall-sown wheat cultivars mostly grown on irrigated land. Karnal bunt is apparently established in the following countries: Mexico, Afghanistan, India, Pakistan, Iran, Iraq, Nepal $(39,40)$, Brazil (12), and South Africa (11). In gen-

Corresponding author: G. L. Peterson

E-mail: gary.peterson @ ars.usda.gov

The use of trade, firm, or corporation names in this publication (or page) is for the information and convenience of the reader. Such use does not constitute an official endorsement or approval by the USDA or the ARS of any product or service to the exclusion of others that may be suitable.

Accepted for publication 10 August 2008.

doi:10.1094/PDIS-92-12-1604

This article is in the public domain and not copyrightable. It may be freely reprinted with customary crediting of the source. The American Phytopathological Society, 2008. eral, the observed agronomic losses attributed to the disease are minimal; however, because of the regulatory status of the pathogen, the potential economic losses due to trade restrictions and subsequent disease management costs could be significant $(2,7-9,17,25,26)$.

Unlike the other wheat bunt pathogens (T. contraversa, T. tritici, and T. laevis) which are generally considered only as grain-quality issues, $T$. indica-infested wheat is considered by many countries as a phytosanitary pest, regardless of its infrequent effect on grain quality $(30,31)$. In response, the United States Department of Agriculture (USDA) initiated measures to reduce the risk of the $T$. indica contaminated domestic grain entering U.S. wheat export elevators. Steps taken include regulating all fields where Karnal bunt of wheat has been found, testing wheat fields within a $4.8-\mathrm{km}$ radius of a known infested field (1), and encouraging frequent soil cultivation of the infested fields to promote natural teliospore degradation and germination in the absence of the host. A national survey of the remaining wheat production areas in the United States is conducted yearly to confirm that the disease has not spread outside the known affected areas.

The application of physical or chemical methods to kill teliospores in an infested field would reduce the likelihood of future infection and teliospore contamination of wheat. Fumigation of soil with methyl bromide $(27,35)$ or methyl iodide $(27)$ is a very effective way to reduce levels of viable $T$. indica teliospores. However, methyl iodide is not currently in significant commercial production and methyl bromide, because of ecological issues, rising cost, a ban on its use in Arizona, and the planned removal from use in the United States, is a poor candidate for future disease management.

The use of soil solarization has been studied extensively over the last 30 years for control of soilborne plant pathogens $(19,20,28,32,37,38)$. In limited microplot studies in India, soil solarization devitalized $T$. indica teliospores in the soil $(33,34)$. The objective of our study was to determine the efficacy of soil solarization to eliminate viable teliospores from a wheat field in Maricopa, AZ. The advantages of such a method are that it could be applied following harvest to quickly reduce the number of teliospores in the soil, reduce windblown spread of viable teliospores to adjacent fields, and serve to provide justification for deregulation of an infested field.

\section{MATERIALS AND METHODS}

Research site. The research site was located within a Karnal bunt-regulated area near the town of Maricopa, AZ, at global positioning system coordinates N $32^{\circ} 59.1441$, W112 2.97966 . Research was conducted under Federal and State permits. The soil type was Sasco clay loam with pH 7.4 and $2.2 \%$ organic matter. The experiment was repeated in 2003 (4 June to 13 July), 2005 (4 June to 7 July), and 2006 (3 June to 12 July). Because of water allocation budgets and cost, the fields were not irrigated prior to solarization. Existing postharvest soil moisture levels were monitored during the study.

Sample preparation. In 2003, teliospores of an Arizona isolate of $T$. indica were harvested from bunted kernels obtained from wheat plants inoculated by boot injection with $1.0 \times 10^{4}$ sporidia/ml $(1$ $\mathrm{ml}$ per wheat spike) in the USDAAgricultural Research Service (ARS), BL3 Plant Disease Containment Facility at Fort Detrick, MD (24). Fungal sori in bunted seed produced above were physically ruptured to release teliospores which were suspended in $35 \mathrm{ml}$ of a $0.12 \%$ Tween-20 (polyoxyethylene sorbitan monolaurate) solution, then placed on an 
orbital shaker $(190 \mathrm{rpm})$ for $15 \mathrm{~min}$. The suspension was poured first through a 53$\mu \mathrm{m}$ mesh nylon sieve (Spectrum, Los Angeles) to remove large debris, then through a 20- $\mu \mathrm{m}$ mesh sieve to capture the teliospores. Teliospores on the screen were rinsed into a beaker and the concentration determined using a Howard mold-counting chamber (Hausser Scientific, Horsham, PA). The final concentration was adjusted by dilution to $1.0 \times 10^{5}$ teliospores $/ \mathrm{ml}$.

Small nylon bags $\left(5 \mathrm{~cm}^{2}\right)$ with $20-\mu \mathrm{m}$ mesh openings were loaded with $3 \mathrm{~g}$ of soil. The soil, originating from the study site, was air dried and sieved (Seedburro Equipment Company, Chicago) to select particles smaller than $0.4 \mathrm{~mm}$ in diameter prior to infesting. A $200-\mu \mathrm{l}$ aliquot containing approximately $2.0 \times 10^{4}$ teliospores was pipetted directly into soil within each bag and the infested soil allowed to air dry.

In 2005 and 2006, three bunted kernels with intact sori were placed directly into the bags with the field soil. The bunted kernels originated from wheat plants field inoculated by boot injection $\left(1.0 \times 10^{4}\right.$ sporidia/ml, $1.0 \mathrm{ml}$ per wheat boot) in the Arizona test plots the previous season. After soil was infested, bags were sealed with plastic tape and identification tags were attached with nylon strings.

Soil solarization and sample burial. Each June, immediately after wheat was harvested, an area of field 213 by $2.5 \mathrm{~m}$ wide was selected. Within this area, the remaining wheat stubble was mowed to a height of $5 \mathrm{~cm}$ and two parallel $30-\mathrm{cm}-$ deep trenches (3.0 m apart) were dug outside the plot area using a tractor equipped with a rear land blade. The experimental area was divided into three blocks. Within each block, five burial locations were spaced $3 \mathrm{~m}$ apart. At each location, three sample bags were buried in a vertical column at depths of 5,10, and $20 \mathrm{~cm}$ with attached strings and terminal identification tags extending to the ground surface.

Plastic sheets ( 76 by $3 \mathrm{~m}$ ) were unrolled over the plot area and the edges were draped into the trenches. Multiple pieces were needed to completely cover the area; therefore, the ends were overlapped by $1 \mathrm{~m}$ and sealed with plastic tape. The trenches were backfilled using the rear land blade and shovels to anchor the plastic. In 2003 and 2005, the plastic utilized was a clear, 0.15-mm-thick (6-mil) polyethylene film (PE film; Film-Guard; Covalence Plastic, Minneapolis, MN). In 2006, the plastic was a clear, 0.075-mm-thick (3-mil), UVresistant, polyethylene film (Green-Tek, Edgerton, WI).

Sample identification tags, visible under the PE film, were pulled through a small incision in the plastic directly over each burial site. Each incision was resealed with plastic tape, leaving the tags with strings attached to the buried samples on the surface of the plastic to aid in sample recovery. Under the USDA Animal and Plant
Health Inspection Service (APHIS) permit conditions, samples could not be buried outside the solarization area. Therefore, nonsolarized samples consisted of nine bags of soil infested with teliospores or bunted kernels that were stored indoors in envelops throughout the study at 20 to $23^{\circ} \mathrm{C}$.

Environmental data. Soil temperature under the plastic was recorded every hour using two Hobo Optic Stow-A-Way temperature loggers (Onset Computer Corporation, Bourne, MA) buried at 5- and 20$\mathrm{cm}$ depths. Volumetric soil moisture levels under the PE film also were recorded at the 5-cm depth every hour using a buried Theta Probe (type ML2x; Delta-T Devices, Ltd., Cambridge, UK) and THLog data logger (Dynamax, Houston). Soil temperatures also were recorded at $5-\mathrm{cm}$ depths in soil not covered by plastic. In 2005, a combination of UV degradation of the PE film and a severe weather event tore the plastic cover 6 days prior to the scheduled removal; therefore, all soil temperature and moisture calculations for that year are based on 32 days of solarization rather than 38 .

Sample retrieval. Buried samples were retrieved at approximately 7-day intervals, with the last samples recovered after 38 days. The 38-day time period was limited by the traditional planting date for rotational crops in the study field. At each sampling, one sample bag was removed at all three burial depths from a single burial location within each block. Incisions in the solarization PE film were resealed after sample retrieval with plastic tape. All retrieved bags were stored indoors with the nonsolarized samples at 20 to $23^{\circ} \mathrm{C}$ until the final sampling at 38 days. All test samples were then shipped under APHIS permit to the ARS Plant Disease Containment Facility at Fort Detrick, MD, for processing.

Teliospore recovery from sample bags. All soil (and bunted kernels in samples from 2005 and 2006) was removed from each mesh bag and placed in a 50-ml centrifuge tube. A $35-\mathrm{ml}$ solution of Tween-20 (3 drops per $100 \mathrm{ml}$ ) was added to each tube, and tubes were shaken on an orbital shaker (190 rpm) for $15 \mathrm{~min}$ to free teliospores from soil or bunted kernels. If necessary, forceps were used to physically dislodge teliospores from the infected kernels. The suspension was poured through a 53- $\mu \mathrm{m}$ mesh nylon sieve and collected in a beaker. Contents remaining on the sieve were rinsed with $500 \mathrm{ml}$ of pressurized water using a garden hose spray attachment. The filtrate was then poured through a $20-\mu \mathrm{m}$ mesh sieve and rinsed with a fine stream of $100 \mathrm{ml}$ of water using an aspirator bottle. Teliospores remaining on the sieve were rinsed with water into a 50-ml centrifuge tube. All sieves were soaked in $1.3 \%$ sodium hypochlorite solution for $15 \mathrm{~min}$ and rinsed between samples to avoid cross contamination. Teliospore suspensions were incubated at $17^{\circ} \mathrm{C}$ for 1 to 3 days to encourage hydration and germination of non-Tilletia fungi to make them more susceptible to the following teliospore surface sterilization technique.

Teliospore suspensions were centrifuged at $913 \times g$ for $5 \mathrm{~min}$ and the remaining pellet was suspended in $2 \mathrm{ml}$ of sterile, $0.1 \%$ water agar. A $100-\mu l$ to $2-\mathrm{ml}$ aliquot of suspension (depending on pellet volume) was transferred to a $15-\mathrm{ml}$ centrifuge tube and treated with $10 \mathrm{ml}$ of acidic electrolyzed water (AEW) to rid samples of unwanted microorganisms $(6,27)$. Samples were mixed on a rocker for $30 \mathrm{~min}$ and then centrifuged at $913 \times g$ for $5 \mathrm{~min}$. The pellet with teliospores was resuspended in sterile water. Centrifuge-wash steps were repeated twice. After the final wash, pellets were suspended in sterile water and prepared for plating on $2 \%$ water agar with streptomycin sulfate $(100 \mathrm{mg} / \mathrm{liter})$ and ampicillin (100 mg/liter) (WASSA). The subsequent processing varied and depended upon whether the original sample included the bunted kernels or contained only loose teliospores.

Germination assay for samples infested with bunted kernels. The sample volume was adjusted to a final concentration of 500 teliospores $/ \mathrm{ml}$ (estimated using a Howard mold-counting chamber). A micropipette was used to deliver a 300- $\mu$ l drop of teliospore suspension to each petri plate containing WASSA. Plates were incubated at $17^{\circ} \mathrm{C}$. After 14 days, percent germination was determined by examining 100 teliospores in each sample using a dissecting microscope. Plates in which no germinating teliospores were observed were reexamined at 21 days.

Germination assay for samples infested with loose teliospores. Pellets remaining after the final centrifugation wash were resuspended in $300 \mu \mathrm{l}$ of sterile water and the entire suspension (representing 5\% of the original sample pellet) was seeded onto the agar medium and incubated at $17^{\circ} \mathrm{C}$ for 14 days. The number of germinating teliospores was counted using a dissecting microscope $(\times 105.6)$. The high level of soil debris in final suspensions made it difficult to distinguish between nongerminating teliospores and soil particles. In order to estimate the percent teliospore germination, two separate 33.3- $\mu \mathrm{l}$ aliquots from the original pellet $(33.3 \mu \mathrm{l}=$ $1.0 \%$ of original sample pellet) were examined on a glass slide under a coverslip using a compound microscope $(\times 400)$.

Statistical analyses. Analysis of variance using Proc MIXED of the SAS (SAS Institute, Inc., Cary, NC) software system was performed to examine the effects and interactions of sample day and burial depth on percent teliospore germination for each year (2003, 2005, and 2006). A comparison of regressions of germination rates 
against days at various depths was performed using Proc MIXED with maximum likelihood estimation and with replication and replication-day as random effects. Data were plotted against time and data points were censored to exclude that portion of the line after the germination rate had reached zero. Individual contrasts were constructed to test for differences between the slopes of the regression lines among the three depths. A similar procedure was used to compare the rate of decline in teliospore germination among all 3 years by calculating the average percent germination data for each year-sample day combination over all burial depths. A significance level of $P=0.05$ was used in all analyses.

\section{RESULTS}

Effects of soil temperatures. The average daily maximum soil temperatures and ranges recorded under plastic are shown in Table 1 . The mean daily maximum $5-\mathrm{cm}$ depth soil temperatures recorded under PE film in 2003, 2005, and 2006 were 24, 12, and $17^{\circ} \mathrm{C}$, respectively, greater than those observed at the same depth in the open (nonsolarized) soil. During 2003, 2005, and 2006, the mean daily maximum temperatures at the $20-\mathrm{cm}$ depth under plastic were, $0,-3$, and $1^{\circ} \mathrm{C}$, respectively, less or greater than the temperatures recorded at the $5-\mathrm{cm}$ open soil depth.

The greatest temperature fluctuations between average minimum and maximum daily soil temperatures under PE film were observed at the 5 -cm depth with an average range of 38,23 , and $35^{\circ} \mathrm{C}$ during 2003 , 2005, and 2006, respectively. Differences of only 9,4 , and $7^{\circ} \mathrm{C}$ were recorded at 20 $\mathrm{cm}$ during the same years, respectively. In 2003, 2005, and 2006, the mean temperature ranges of the open soil were 23,21 , and $21^{\circ} \mathrm{C}$, respectively.

The total number of hours that soil temperatures remained below $20^{\circ} \mathrm{C}$ and those that exceeded $20,30,40,50,60$, and $70^{\circ} \mathrm{C}$ ( 20 to 70,30 to 70 , and so on) are shown in Table 2 by year, depth, and treatment. The open soil temperature at $5 \mathrm{~cm}$ remained below $30^{\circ} \mathrm{C} 56.7 \%$ of the total study time $\left(8.9 \%\right.$ below $\left.20^{\circ} \mathrm{C}\right)$, whereas the solarized soil temperature remained

Table 1. Average daily minimum (min) and maximum (max) soil temperatures, ranges, and differential recorded at both 5- and 20-cm depths in an Arizona field during solarization under clear plastic, those recorded at the 5-cm depth in nonsolarized soil, and mean air temperatures during the experiments

\begin{tabular}{|c|c|c|c|c|c|c|}
\hline \multirow[b]{3}{*}{ Year, depth ${ }^{\mathrm{a}}$} & \multicolumn{6}{|c|}{ Temperature $\left({ }^{\circ} \mathrm{C}\right)$} \\
\hline & \multicolumn{2}{|c|}{ Mean } & \multicolumn{2}{|c|}{ Range } & \multirow[b]{2}{*}{ Diff. $^{b}$} & \multirow[b]{2}{*}{ Air (range) ${ }^{c}$} \\
\hline & Daily min & Daily max & Daily min & Daily max & & \\
\hline 2003 & & & & & & $31.7(15.5-45.6)$ \\
\hline 5-cm Solarized & 29 & 67 & $21.1-35.8$ & $62.5-70.7$ & 49.6 & $\ldots$ \\
\hline 20-cm Solarized & 34 & 43 & $26.8-37.9$ & $35.3-42.3$ & 15.5 & $\ldots$ \\
\hline 5-cm Nonsolarized & 20 & 43 & $12.9-25.9$ & $37.9-49.8$ & 36.9 & $\ldots$ \\
\hline 2005 & & & & & & $30.0(16.1-45.6)$ \\
\hline 5-cm Solarized & 30 & 53 & $23.2-34.6$ & $38.5-76.0$ & 52.8 & $\ldots$ \\
\hline 20-cm Solarized & 34 & 38 & $26.9-36.8$ & $32.5-40.5$ & 13.6 & $\ldots$ \\
\hline 5-cm Nonsolarized & 20 & 41 & $12.9-30.3$ & $34.9-46.4$ & 33.5 & $\ldots$ \\
\hline 2006 & & & & & & $31.7(19.6-44.4)$ \\
\hline 5-cm Solarized & 25 & 60 & $17.9-30.3$ & $37.5-67.1$ & 49.2 & $\ldots$ \\
\hline 20-cm Solarized & 37 & 44 & $28.1-40.6$ & $35.8-46.4$ & 18.3 & $\ldots$ \\
\hline 5-cm Nonsolarized & 22 & 43 & $13.5-29.5$ & $36.1-45.9$ & 44.4 & $\ldots$ \\
\hline
\end{tabular}

${ }^{a}$ Experiments were conducted 4 June to 13 July 2003, 4 June to 7 July 2005, and 3 June to 12 July 2006.

${ }^{\mathrm{b}}$ Difference between the lowest minimum and highest maximum daily temperatures recorded.

${ }^{\mathrm{c}}$ Range of mean air temperatures. below $30^{\circ} \mathrm{C}$ only 19.8 and $1.3 \%(0.5$ and $0 \%$ below $20^{\circ} \mathrm{C}$ ) at the depths of 5 and 20 $\mathrm{cm}$, respectively.

Soil moisture. In all years, the level of hourly soil moisture recorded at $5 \mathrm{~cm}$ fluctuated daily, with the lower moisture levels occurring at approximately 7:00 a.m. and the highest level $12 \mathrm{~h}$ later, when the greatest amount of water condensation was observed on the underside of the PE film (Table 3). The average soil moisture levels in 2003 and 2005 were 5.05 and $6.65 \%$ ( $\mathrm{vol} / \mathrm{vol}$ ) compared with $10.51 \%$ in 2006 .

Teliospore germination. Nonsolarized ( 0 day) mean teliospore germination rates of 43,71 , and $82 \%$ were reduced to 0.1 , 7.7, and $0.2 \%$ after 38 days (across all depths) in 2003, 2005, and 2006, respectively (Fig. 1). In 2005, the 6-mil PE film was torn after 32 days; therefore, solarization conditions did not occur for a full 38 days. During that year, germination rates were reduced to less than $2.0 \%$ in all but two buried samples, which maintained the higher germination rate that contributed to the final $7.7 \%$ reported after 38 days. These two samples were retrieved from a single burial column within a block.

There were no significant differences in the resulting slopes in 2003 or 2005, suggesting no differences in the rate of teliospore decline attributed to burial depth (Fig. 2A and B). In 2006 (Fig. 2C), teliospores buried at $20 \mathrm{~cm}$ had a slower rate of decline than those buried at 5 and $10 \mathrm{~cm}$ during the first 14 days of the study. After 21 days, teliospore viability approached zero at all three depths (Table 4).

When mean germination data for each depth was plotted against time (Fig. 2), the slopes were significantly greater in 2006 than the slopes in $2003(P=0.0073)$ and $2005(P=0.0038)$. In contrast, slopes in 2003 and $2005(P=0.7622)$ were similar.

\section{DISCUSSION}

In these tests, soil solarization clearly reduced the number of viable $T$. indica teliospores in the soil to near zero after 38 days. There were no appreciable differences in the number of viable teliospores

Table 2. Length of teliospore exposure (hours) to specific temperatures of soil solarization and nonsolarized control field plots

\begin{tabular}{|c|c|c|c|c|c|c|c|}
\hline \multirow[b]{2}{*}{ Year, depth ${ }^{b}$} & \multicolumn{7}{|c|}{ Exposure (h) at temperature $\left({ }^{\circ} \mathbf{C}\right)^{\mathbf{a}}$} \\
\hline & $<\mathbf{2 0}$ & $\geq \mathbf{2 0}$ & $\geq \mathbf{3 0}$ & $\geq \mathbf{4 0}$ & $\geq \mathbf{5 0}$ & $\geq 60$ & $\geq 70$ \\
\hline \multicolumn{8}{|l|}{2003} \\
\hline 5-cm Solarized & 0 & 922 & 803 & 493 & 342 & 198 & 2 \\
\hline 20-cm Solarized & 0 & 922 & 910 & 166 & 0 & 0 & 0 \\
\hline 5-cm Nonsolarized & 103 & 819 & 530 & 190 & 0 & 0 & 0 \\
\hline \multicolumn{8}{|l|}{2005} \\
\hline 5-cm Solarized & 0 & 767 & 705 & 368 & 117 & 0 & 0 \\
\hline 20-cm Solarized & 0 & 767 & 743 & 17 & 0 & 0 & 0 \\
\hline 5-cm Nonsolarized & 99 & 668 & 414 & 95 & 0 & 0 & 0 \\
\hline \multicolumn{8}{|l|}{2006} \\
\hline 5-cm Solarized & 14 & 896 & 585 & 342 & 229 & 72 & 0 \\
\hline 20-cm Solarized & 0 & 910 & 908 & 504 & 0 & 0 & 0 \\
\hline 5-cm Nonsolarized & 44 & 866 & 513 & 224 & 0 & 0 & 0 \\
\hline
\end{tabular}

a Temperature nodes refer to total exposure hours $<$ or $\geq$ that specific soil temperature (e.g., $\geq 20=20$ to $70^{\circ} \mathrm{C}$ ).

${ }^{b}$ Experiments were conducted 4 June to 13 July 2003, 4 June to 7 July 2005, and 3 June to 12 July 2006. 
recovered from 5-, 10-, and 20-cm depths after 21 days of solarization despite a significant difference in soil temperature ranges recorded at 5 and $20 \mathrm{~cm}$. Daily soil temperatures were highest at $5 \mathrm{~cm}$; however, temperatures at the $20-\mathrm{cm}$ depth remained closer to daytime temperatures at night, resulting in a higher number of cumulative hours at temperatures above $30^{\circ} \mathrm{C}$ compared with the 5-cm depth. This suggests that sustained exposure to lower temperatures $\left(30\right.$ to $40^{\circ} \mathrm{C}$ ) may be as detrimental to spore viability as shorter exposures to the higher temperatures (above $40^{\circ} \mathrm{C}$ ) encountered in the field. It is likely that loss of 6 days of solarization exposure in 2005 accounted for greater numbers of viable teliospores being recovered $(7.7 \%$ germination) at the 38-day sampling that year; or, alternatively, there may have been a leak in the taped incision over the burial column that contained the only two samples with elevated germination, which would have allowed heat to escape; however, this is not known to be fact

The minimum temperature during solarization was more important to teliospore survival than the maximum temperature or soil depth. Average maximum daytime nonsolarized soil temperatures at $5 \mathrm{~cm}$ were greater than or equal to the maximum soil temperatures recorded under solarization for $20 \mathrm{~cm}$; however, minimum nonsolarized temperatures were approximately $14^{\circ} \mathrm{C}$ lower than those observed at the 20 $\mathrm{cm}$ soil depth under plastic. In all 3 years, the mean daily maximum and minimum temperature range achieved at $20 \mathrm{~cm}$ under plastic was approximately 44 to $34^{\circ} \mathrm{C}$, whereas the mean temperatures ranges recorded in the open soil were approximately 43 to $20^{\circ} \mathrm{C}$. This indicates that daily cycling into these upper temperature ranges was not immediately lethal to teliospores but does suggest that sustained temperatures above $34^{\circ} \mathrm{C}$ were detrimental over time. Soil at the $20-\mathrm{cm}$ depth under PE film accumulated an average of 387 more hours of temperatures above $30^{\circ} \mathrm{C}$ compared with nonsolarized soil at $5 \mathrm{~cm}$ in all years. This is a common observation in many soil solarization studies with soilborne pathogens and is known as the cumulative effect of sublethal temperature exposure over time $(18,22)$.

In a separate study begun in July 1996 (G. L. Peterson and K. L. Kosta, unpublished data) in Blythe, CA (N33 36.61218 , $\mathrm{W} 114^{\circ} 35.71932$ ), bunted kernels and free teliospores were buried in $20-\mu \mathrm{m}$ mesh nylon bags at depths of 0,10 , and $20 \mathrm{~cm}$ under replicated $9-\mathrm{m}^{2}$ 0.075-mm PE film. The field had been pre-irrigated and determined to be at field capacity when the study began. Controls were buried outside the solarization tarps. Samples were recovered at 30 and 60 days. The average $5-\mathrm{cm}$ soil temperature under the $\mathrm{PE}$ film was $62.3^{\circ} \mathrm{C}$, with a range of 40 to $74.5^{\circ} \mathrm{C}$. Combining the results across all depths, the mean teliospore germination rates were 0.72 and $0.3 \%$ after 30 and 60 days of solarization, respectively. Germination percentages for teliospores buried in open soil (controls) were 38.0 and $38.3 \%$ at 30 and 60 days, respectfully. The solarization results from that study were similar to those we observed in Maricopa, AZ, suggesting that solarization also would work in the small $T$. indica-infested areas of California.

As reported in similar studies with other fungal plant pathogens, the rate of pathogen decline is correlated with moisture in the soil (21). No significant difference was shown in the rate of teliospore decline between 2003 and 2005 but there was an appreciable difference when both were compared with the results from 2006. Though our studies suggested that higher moisture may have been a significant factor in rate of teliospore decline during the early weeks of 2006, this difference was no longer observed 21 days after solarization began, when germination levels in the solarized samples reached or neared zero in all years. These data and those from similar studies suggest that, if water is available, irrigation of the field prior to solarization would accelerate the rate of teliospore decline. In all three experiments, volumetric soil moisture levels were below the wilting point for clay loam field soil $(18 \%)$ and well below water-holding capacity $(29 \%)$. Also, data suggest that extension of the solarization period beyond 38 days without presolarization irrigation may further reduce the residual levels of viable teliospores observed in this study.

These results were similar to those obtained by Haroon-Usmani et al. (15), in which soil solarization devitalized sclerotia of Sclerotium oryzae in both wet and dry soils. After 1 week, all sclerotia in wet soil (96 to $100 \%$ ) were killed whereas, in dry soil, sclerotia viability was similarly reduced by 95 to $100 \%$ after 2 weeks (15).

Smilanick et al. (35) reported over $98 \%$ efficacy in killing $T$. indica teliospores in soil using methyl bromide at $570 \mathrm{~kg} / \mathrm{h}$ under tarp, while Peterson et al. (27) reported $99.56 \%$ (range 100 to $93 \%$ ), $100 \%$ (no variation), and $99.99 \%$ (range 100 to $99.7 \%$ ) control at 337,449 , and $560 \mathrm{~kg} / \mathrm{h}$, respectively. These data are comparable with results obtained after 38 days of soil solarization in this study (i.e., kill of $99.9 \%$, range 99.0 to $100 \%$ and $99.8 \%$, range 99.0 to $100 \%$ in 2003 and 2006, respectively). Soil solarization efficacy of

Table 3. Average of daily maximum (max) and minimum (min) percent volumetric soil moisture and range recorded at a depth of $5 \mathrm{~cm}$ under clear solarization plastic in a Maricopa, AZ test field

\begin{tabular}{|c|c|c|c|c|c|}
\hline \multirow[b]{3}{*}{ Yeara $^{\mathbf{a}}$} & \multicolumn{5}{|c|}{ Soil moisture (\%) } \\
\hline & \multicolumn{2}{|c|}{ Mean } & \multicolumn{2}{|c|}{ Mean range } & \multirow[b]{2}{*}{$\operatorname{Mean}(\mathbf{S D})^{\mathrm{b}}$} \\
\hline & Daily min & Daily max & Daily min & Daily max & \\
\hline 2003 & 3.4 & 6.1 & $1.6-7.9$ & $5.5-8.4$ & $5.1(0.95)$ \\
\hline 2005 & 5.1 & 8.4 & $2.1-6.4$ & $2.5-9.8$ & $6.6(1.7)$ \\
\hline 2006 & 8.2 & 12.7 & $6.4-9.8$ & $11.3-15.2$ & $10.5(1.5)$ \\
\hline
\end{tabular}

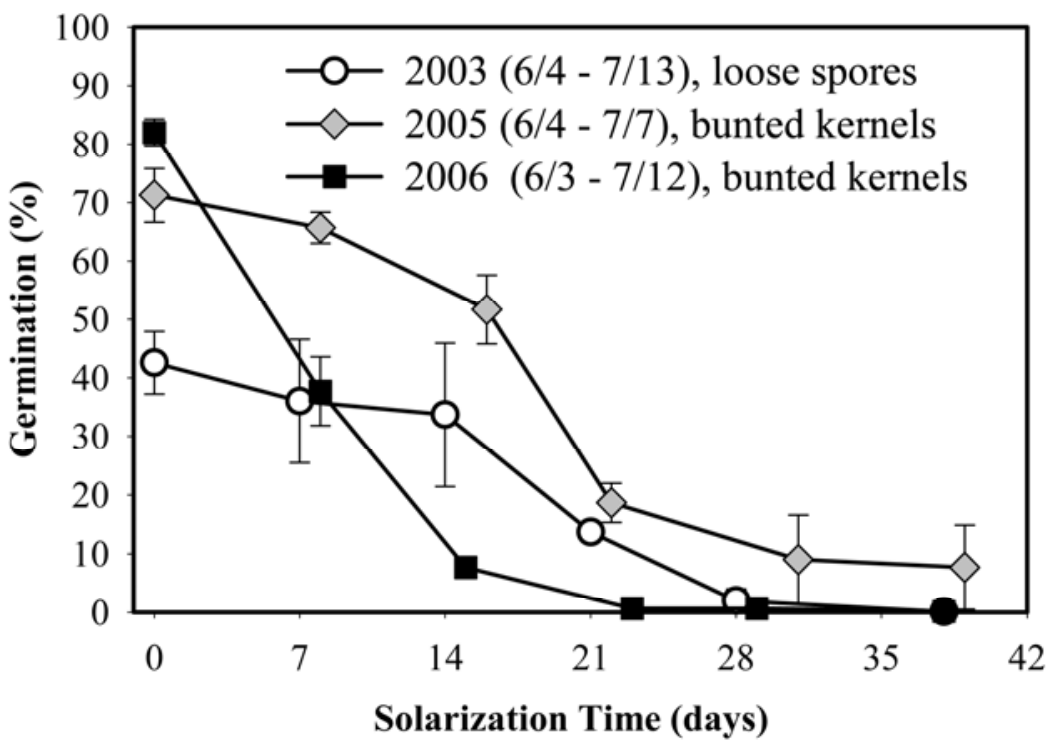

Fig. 1. Percentage of germinating Tilletia indica teliospores recovered each year after exposure to solarization. Time data (depth) were pooled within year to obtain the averages and standard deviation bars. 

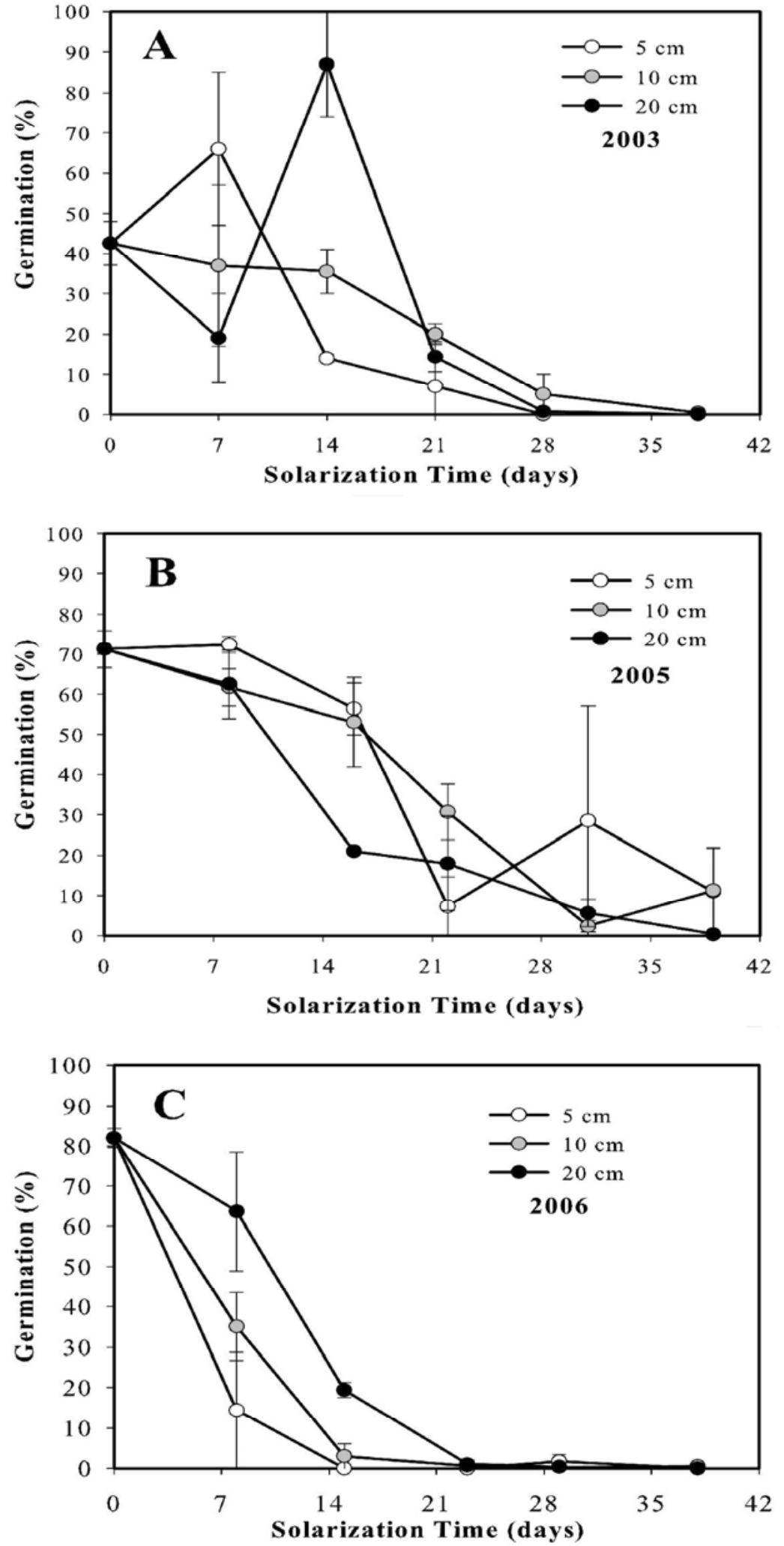

Fig. 2. Length of solarization period and viability of Tilletia indica teliospores in each of 3 years. In A, 2003 (4 June to 13 July) and B, 2005 (4 June to 7 July), mixed model analysis of variance did not show depth to be a significant factor; however, in C, 2006 (3 June to 12 July), statistically significant differences in the slope from the $20-\mathrm{cm}$ depth data verses the slopes of the 5- and 10-cm data were detected. Standard deviation bars are shown.

teliospore mortality for 2005 was $92.4 \%$ (range 67 to $100 \%$ ) after 32 days under PE film.

Under the current USDA-APHIS Karnal bunt management scheme (1), a field that had previously tested positive for the presence of $T$. indica-infected grain, along with the surrounding $4.8-\mathrm{km}$ buffer zone, could be removed from regulation by meeting one of the following two requirements.
Either the affected field is permanently removed from crop production or the field is tilled at least once per year for a total of 5 years (the years need not be consecutive). After tilling, the field may be planted with a crop or left fallow. If the field is planted with a host crop, the crop must test negative (based on the absence of bunted kernels).

The reasoning behind the first criterion is obvious. The justification for the second criterion is based both on research documenting a measure of decline in the viability of $T$. indica teliospores over time $(4,5,16,36)$ and the premise that teliospores brought to the soil surface by cultivation would germinate in the absence of the host when environmental conditions were favorable, two factors leading to the depletion of viable teliospores over time.

Based on this assertion, it is likely that utilization of a chemical or physical method that would directly kill teliospores in an infested field would satisfy requirements for the removal of regulatory restrictions much more quickly. Such a procedure could be applied immediately after harvest when a field tested positive for bunted kernels, shortening significantly the 5-year regulatory period and reducing costs associated with monitoring and loss of production. Precedent for the approach was established in 1996 when methyl bromide soil fumigation was used to prevent regulatory restrictions on several small fields in California and Washington $(3,13)$ which had been planted with wheat seed allegedly contaminated with $T$. indica teliospores.

In 2006, the cost of solarization was estimated to be US $\$ 10,380 /$ ha. This includes (i) manufacture of $0.075-\mathrm{mm}$ UV-resistant $\mathrm{PE}$ film to the specifications required to fit commercial application equipment (Gothic Arch Greenhouses, Mobile, AL), (ii) mechanical application of continuous clear plastic over the field (TriCal, Inc., Hollister, CA), and (iii) removal and disposal of the plastic at the end of the solarization period (Salinas Tarp Pullers, Salinas, CA). In contrast, cost estimates for the application of methyl bromide at a rate of 393 $\mathrm{kg} / \mathrm{ha}$ under PE film ranged from US $\$ 5,685$ to $6,179 /$ ha (TriCal, Inc.). Current cost estimates for both methods would vary significantly based on the price of crude oil at the time of plastic film manufacturing.

Despite the positive implications of our study, methyl bromide still has several advantages over soil solarization. In regions of the United States where commercial methyl bromide application is still permitted, the cost of fumigation would be significantly less than that of soil solarization. Additionally, the treatment period is much shorter for methyl bromide ( 2 to 3 days), thus reducing risk of inclement weather, wandering livestock, or other circumstances damaging the PE film cover. 
Table 4. Analysis of variance using the Mixed procedure analysis comparing germination data by burial depth over time for each year

\begin{tabular}{lrllll}
\hline Year, comparisons & \\
\hline 2003 & Estimate & $\mathbf{S E}^{\mathbf{b}}$ & df & $\boldsymbol{t}$ Value & $\boldsymbol{P}<|\mathbf{t}|$ \\
$5 \mathrm{~cm}$ vs. $10 \mathrm{~cm}$ & -0.2517000 & 0.6970 & 36 & -0.36 & 0.7202 \\
$5 \mathrm{~cm}$ vs. $20 \mathrm{~cm}$ & -0.2303000 & 0.6970 & 36 & -0.33 & 0.7430 \\
$10 \mathrm{~cm}$ vs. $20 \mathrm{~cm}$ & 0.0213400 & 0.6707 & 36 & 0.03 & 0.9748 \\
2005 & & & & & \\
$5 \mathrm{~cm}$ vs. $10 \mathrm{~cm}$ & 0.0007889 & 0.3819 & 36 & 0.02 & 0.9836 \\
$5 \mathrm{~cm}$ vs. $20 \mathrm{~cm}$ & -0.1274000 & 0.4102 & 36 & -0.31 & 0.7565 \\
$10 \mathrm{~cm}$ vs. $20 \mathrm{~cm}$ & -0.1355000 & 0.4077 & 36 & -0.33 & 0.7404 \\
2006 & & & & & \\
$5 \mathrm{~cm}$ vs. $10 \mathrm{~cm}$ & 0.6502000 & 0.5068 & 37 & 1.28 & 0.2076 \\
$5 \mathrm{~cm}$ vs. $20 \mathrm{~cm}$ & 1.7226000 & 0.5068 & 37 & 3.40 & $0.0016^{\mathrm{c}}$ \\
$10 \mathrm{~cm}$ vs. $20 \mathrm{~cm}$ & 1.0725000 & 0.5068 & 37 & 2.12 & $0.0411^{\mathrm{c}}$ \\
\hline
\end{tabular}

a Year and slope comparisons for burial depths shown. Experiments were conducted 4 June to 13 July 2003, 4 June to 7 July 2005, and 3 June to 12 July 2006.

b Standard error.

c Differences are significant if $P \leq 0.05$.

Despite this, some states such as Arizona have outlawed the use of methyl bromide soil fumigation. Other alternative soil fumigants have only limited effect on $T$. indica teliospores in soil. (27); therefore, solarization may be the only practical approach. In addition, if used as an approach to deregulation, costs of solarization would be offset further by eliminating the expense of regulatory personnel over the 5year period required for monitoring and laboratory testing.

In this study in central Arizona, soil solarization applied soon after harvest significantly reduced the number of viable teliospores in the soil to a depth of $20 \mathrm{~cm}$ without the need to irrigate the field prior to solarization. Maximum and minimum soil temperatures at 5 and $20 \mathrm{~cm}$ were similar to those reported in other soil solarization studies for controlling soilborne pathogens in California $(18,37)$, New Mexico, Texas, and Israel $(14,21)$. Historically, solarization has been most effective in hot, arid, mostly cloudless regions with little rainfall (10), climates equivalent to the geographic areas where Karnal bunt currently occurs in the United States. Soil solarization temperature models have been developed $(23,41)$ and data from this study could be included with local and regional environmental output for prediction of areas of the United States where soil solarization would likely be useful for control of Karnal bunt.

\section{ACKNOWLEDGMENTS}

We thank L. Pratt, J. Pratt, D. Pratt, and D. Pratt, Pratt Farms, Maricopa, AZ and Biological Science Technician K. Fronda, USDA-ARS FDWSRU, Fort Detrick, MD for their the support, contributions, and participation.

\section{LITERATURE CITED}

1. Anonymous. "Karnal Bunt." 2006. Pages 123139 in: Title 7 Code of Federal Regulations, Pt 301, 2006 ed.

2. Beattie, B. R., and Biggerstaff, D. R. 1999. Karnal bunt, a wimp of a disease - but an irresistible political opportunity. Choices, Second Quarter, 1999:4-8.

3. Biggerstaff, D. 1996. Karnal bunt: Experiences of a North-South Breeding Company. APS
Karnal bunt Symposium. http://www.apsnet. org/online/proceedings/karnal/kbspaper/artw pb1.htm

4. Bonde, M. R., Berner, D. K., Nester, S. E., Peterson, G. L., Olsen M. W., Cunfer, B. M., and Sim, T. 2004. Survival of Tilletia indica teliospores in different soils. Plant Dis. 88:316324.

5. Bonde, M. R., Nester, S. E., Olsen, M. W., Berner, D. K., and Olsen, M. W. 2004. Survival of teliospores of Tilletia indica in Arizona field soils. Plant Dis. 88:804-810.

6. Bonde, M. R., Nester, S. E., Schaad, N. W., Frederick, R. D., and Luster, D. G. 2003. Improved detection of Tilletia indica teliospores in seed or soil by elimination of contaminating microorganisms with acidic electrolyzed water. Plant Dis. 87:712-718.

7. Bonde, M. R, Peterson, G. L, Schaad, N. W, and Smilanick, J. L. 1997. Karnal bunt of wheat. Plant Dis. 81:1370-1377.

8. Brennan, J. P., and Warham, E. J. 1989. Economic losses from Karnal bunt of wheat in Mexico. Rep. Joint CIMMYT-INIFAP Study. CIMMYT, Mexico.

9. Brennan, J. P., Warham, E. J., Byerlee, D., and Hernandez-Estrada, J. 1992. Evaluating the economic impact of quality-reducing, seedborne diseases: lessons from Karnal bunt of wheat. Agric. Econ. 6:345-352.

10. Chellemi, D. O., Olson, S. M., and Mitchell, D. J. 1994. Effects of soil solarization and fumigation on survival of soilborne pathogens of tomato in northern Florida. Plant Dis. 78:11671172.

11. Crous, P. W., Van Jaarsveld, A. B., Castlebury, L. A., Carris, L. M., Frederick, R. D., and Pretorius, Z. A. 2001. Karnal bunt of wheat newly reported from the African continent. Plant Dis. 85:561.

12. Da Luz, W. C., Mendes, M. A. S., Ferreira, M. A. S. V., and Urben, A. F. 1993. Tilletia indica on wheat in the south of the state of Rio Grande do Sul, Brazil and measures for eradication. Fitopatol. Bras. 18:S329.

13. Fulton, A., Wright, S., and Jackson, L. 1996. Small Grain News. University of California Cooperative Extension, Tulare County.

14. Grinstein, A., Katan, J., Razik A., Zeidan, O., and Elad, Y. 1979. Control of Sclerotium rolfsii and weeds in peanuts by solar heating of the soil. Plant Dis. Rep. 63:1056-1059.

15. Haroon-Usmani, S. M., and Ghaffar, A. 1982. Polyethylene mulching of soil to reduce viability of sclerotia of Sclerotium oryzae. Soil Biol. Biochem. 14:203-206.

16. Inman, A., Magnus, H. A., Riccioni, L., Hughes, K., Coates, M., Barnes, A., Barton, V., Sansford, C., Valvassori M., Di Giambattista, G., Porta-Puglia, A, Razzaghian, J., and Peter- son, G. Survival of Tilletia indica teliospores under European soil conditions. Plant Pathol. In press.

17. Joshi, L. M., Singh, D. V., Srivastava, K. D. and Wilcoxson, R. D. 1983. Karnal bunt: a minor disease that is now a threat to wheat. Bot. Rev. 49(4):309-330.

18. Juarez-Palacios, C., Felix-Gastelum, R., Wakeman, R. J., Paplomatas, E. J., and DeVay, J. E. 1991. Thermal sensitivity of three species of Phytophthora and the effect of soil solarization on their survival. Plant Dis. 75:1160-1164.

19. Katan, J. 1980. Solar pasteurization of soils for disease control: Status and prospects. Plant Dis. 64:450-454.

20. Katan, J. 1981. Solar heating (solarization) of soil for control of soilborne pests. Annu. Rev. Phytopathol. 19:211-236.

21. Katan, J., Greenberger, A., Alon, H., and Greenstein, A. 1976. Solar heating by polyethylene mulching for the control of diseases caused by soil-borne pathogens. Phytopathology 66:683-688.

22. Lopez-Herrera, C. J., Perez-Jimenez, R. M., Basallote-Ureba, M. J., Zea-Bonilla, T., and Melero-Vara. 1997. Effect of soil solarization on the control of Phytophthora root rot in avocado. Plant Pathol. 46:329-340.

23. Mahrer Y. 1979. Prediction of soil temperature of a soil mulched with transparent polyethylene. J. Appl. Meteorol. 18:1293-1267.

24. Melching, J. S., Bromfield, K. R., and Kingsolver, C. H. 1983. The plant pathogen containment facility at Frederick, Maryland. Plant Dis. 67:717-722.

25. Murray, G. M., and Brennan, J. P. 1998. The risk to Australia from Tilletia indica; the cause of Karnal bunt of wheat. Australas. Plant Pathol. 27:212-225.

26. Nagarajan, S., Aujla, S. S., Nanda, G. S. Sharma, I., Goel, L. B., Kumar, J., and Singh D. V. 1997. Karnal bunt (Tilletia indica) of wheat: a review. Rev. of Plant Pathol. 76:1207-1214.

27. Peterson, G. L., Kosta, K. L., Hunsaker, D. J., and Boratynski, T. N. 1997. Results of soil fumigations on the viability of Tilletia indica teliospores. Pages 175-181 in: Bunts and Smuts of Wheat: an International Symposium. V. S. Malik and D. E. Mathre, eds. North American Plant Protection Organization, Ottawa, Ontario, Canada.

28. Phillips, A. J. L. 1990. The effects of soil solarization on sclerotial population of Sclerotinia sclerotiorum. Plant Pathol. 39:38-43.

29. Rush, C. M., Stein, J. M., Bowden, R. L., Riemenschneider, R., Boratynski, T., and Royer, M. H. 2005. Status of Karnal bunt of wheat in the United States: 1996 to 2004. Plant Dis. 89:212-223.

30. Sansford, C. 1998. An assessment of the significance of the initial detection of Tilletia indica Mitra in the USA in early 1996 and the potential risk to the United Kingdom (and the European Union). Pages 273-302 in: Bunts and Smuts of Wheat: An International Symposium. W. S. Malik and D. E. Mathre, eds. North American Plant Protection Organization, Ottawa, Ontario, Canada.

31. Sansford, C., Baker, R., Brennan, J., Ewert, F., Gioli, B., Inman, A., Kelly, P., Kinsella, A., Leth, V., Magnus, H., Miglietta, F., Murray, G., Peterson, G., Porta-Puglia, A., Porter, J., Rafoss, T., Riccioni, L., Thornes, F., and Valvassoni, M. 2006. Report on the risk of entry, establishment and economic loss for Tilletia indica in the European Union. EC Fifth Framework Project QLKS-1999-01554: Risks Associated with Tilletia indica, the Newly Listed E.U. Quarantine Pathogen, the Cause of Karnal Bunt of Wheat. http://karnalpublic. pestrisk.net/.

32. Sarraf, S., and Farah, J. 1989. Soil disinfection in Lebanon with solar energy-solarization. Acta Hortic. 245:209-216. 
33. Singh, A. 1994. Epidemiology and management of Karnal bunt disease of wheat. Res. Bull. No. 127. Directorate of Experiment Station, G. B. Pant University of Agriculture and Technology, Pantnagar, India.

34. Singh, B. B., Aujla, S. S., and Sharma, I. 1993. Integrated management of Karnal bunt. Intl. J. Pest Manage. 39:431-434.

35. Smilanick, J. L., and Prescott, J. M. 1986. Effect of soil fumigation with methyl bromide, metham, and formaldehyde on germination of teliospores of Tilletia indica. Phytopathology 76:1060.

36. Smilanick, J. L., Prescott, J. M., and Hoff- mann, J. A. 1987. Survival of teliospores of the Karnal bunt fungus, Tilletia indica, in field soil 1986. Biol. Cult. Tests Control Plant Dis. 42:96-97.

37. Stapleton, J. J., and DeVay, J. E. 1982. Effect of soil solarization in populations selected soil borne microorganisms and growth of deciduous fruit tree seedlings. Phytopathology 72:323-326.

38. Stapleton J. J., and DeVay, J. E. 1986. Soil solarization a non chemical approach for management of plant pathogens and pests. Crop Prot. 5:190-198.

39. Torarbi, M., Mardoukhi, V., and Jalaiani, N.
1996. First report on the occurrence of partial bunt on wheat in the southern parts of Iran. Seed Plant 12:8-9.

40. Warham, E. J. 1986. Karnal bunt disease of wheat: a literature review. Trop. Pest Manage. 32: 229-242.

41. Wu, Y., Perry, K. B., and Ristaino, J. B. 1996. Estimating temperature of mulched and bare soil from meteorological data. Agric. For. Meteorol. 81:299-323.

42. Ykema, R. E., Floyd, J. P., Palm, M. E., and Peterson, G. L. 1996. First report of Karnal bunt of wheat in the United States. Plant Dis. 80:1207. 